J. Clin. Chem. Clin. Biochem.

Vol. 17, 1979, pp. 379-388

\title{
Comparison of Acidic and Basic Chromosomal Proteins from Normal Human Endometrium and Undifferentiated Endometrial Carcinoma by Isoelectric Focussing and Microgel-Electrophoresis
}

\author{
By K. Pollow ${ }^{1}$ ), Helena Fleischer and Barbara Pollow \\ Institut für Molekularbiologie und Biochemie der Freien Universität Berlin
}

(Received October 10,1978/January 24, 1979)

Summary: In the study reported here, non-histone chromosomal proteins from proliferative and secretory human endometrium, and from undifferentiated endometrial carcinoma have been separated into more than 750 protein components, using a new preparative and highly sensitive analytical method. The following experimental procedure was applied:

1. Dissociation of chromatin under different conditions (variable parameters: ion strength, dissociation agents, shearing, $\mathrm{pH}$ ),

2. cation exchange chromatography over Bio Rex,

3. preparative fractionation of those non-histone chromosomal proteins which are not adsorbed on Bio Rex 70 in a Valmet-electrofocusing apparatus,

4. micro-electrophoresis of the focused proteins in microgels containing a continuous gradient of polyacrylamide,

5. two-dimensional electrophoresis of the strongly basic chromosomal proteins.

There are qualitative differences with respect to the components of this class of proteins between proliferative and secretory endometrium and endometrial carcinoma. The relevance of these results to the control of gene activity is discussed.

Vergleich der sauren und basischen chromosomalen Proteine aus normalem Endometrium des Menschen und undifferenziertem Endometrüumcarcinom durch isoelektrische Fokussierung und Mikrogel-Elektrophorese

Zusammenfassung: In der vorliegenden Arbeit wird eine neue Methode zur hochauflösenden Analyse chromosomaler Proteine beschrieben. Die chromosomalen Proteine wurden aus Humanendometrium der Proliferations- und Sekretionsphase sowie aus Gewebeproben undifferenzierter Endometriumkarzinome präpariert. Mehr als 750 Proteinkomponenten konnten mit dieser Methode analytisch erfaßt werden. Der methodische Ablauf ist folgender:

1. Differentielle Dissoziạtion von Chromatin (variable Parameter: Ionenkonzentration, qualitative Zusammensetzung des Puffermediums, pH-Wert, Scherkräfte),

2. Kationaustauschchromatographie mit Bio Rex 70 zur Separierung von Histon- und Nicht-Histon-Proteinkomponenten,

3. Präparative Fraktionierung der chromosomalen Nịcht-Histọn-Proteine durch Isoelektrofokussierung,

4. Mikrogradientengel-Elektrophorese der isoelektrofokussierten chromosomalen Nicht-Histon-Proteine,

5. Zweidimensionale-Gel-Elektrophorese der an Bio Rex 70 adsorbierten stark basischen chromosomalen Proteine.

Die Analyșe zeigte vọ allem qualitative Unterschiede in den Proteinmustèrn zwischen Normalgewebe der Proliferations- und Sekretionsphase sowie Endometriumkarzinom.

Die mögliche biologische Bedeutung dieses Befundes wird diskutiert.

\section{Introduction}

The role of non-histone chromosomal proteins in the control of eucaryotic gene expression is just beginning 1) This work was supported by the Deutsche Forschungsgemein-
schaft 
to be revealed $(1-12)$. In vitro transcription of reconstituted chromatin has shown that the non-histone chromosomal proteins include regulators of transcription of the genes for globins and histones. Changes in non-histone chromosomal proteins in response to specific external hormonal signals have been clearly documented for several hormone-dependent systems.

In this paper we report the isolation and fractionation of chromosomal proteins from normal human endometrium (depending on the phase of the menstrual cycle) and from undifferentiated endometrial carcinoma, using a new separation technique (13-15):

1. about $95 \%$ of the native chromatin proteins is extracted,

2. all the major components of chromatin are separated from one another, and

3. the chromosomal proteins are separated into several major groups by a two-step electrophoretic system.

The first step is isoelectric focussing by means of a Valmet apparatus on a preparative scale; the second is microdisc electrophoresis on SDS-acrylamide gels for acidic chromosomal proteins, or micro-scale twodimensional polyacrylamide gel electrophoresis of strongly basic chromosomal proteins.

\section{Material and Methods}

Isolation of cell nuclei

A total of 86 early proliferative and 61 early secretory human endometria and 38 undifferentiated endometrial carcinoma obtained from hysterectomy or diagnostic curettage were used.
All tissue was subjected to histological examination before homogenization and correlated to the stage of the menstrual cycle using histological examination according to the method of Noyes et al. (16).

The isolation procedure was subsequently carried out at $4{ }^{\circ} \mathrm{C}$ The tissue was homogenized with a Potter-Elvehjem in $0.05 \mathrm{~mol} / 1$ Tris/HCl buffer, $\mathrm{pH} 7.4$, containing $0.025 \mathrm{~mol} / 1 \mathrm{KCl}, 0.01 \mathrm{~mol} / \mathrm{l}$ $\mathrm{MgCl}_{2}, 0.024 \mathrm{~mol} / 1$ thioglycerol, $5 \mathrm{mmol} / 1$ sodium hydrogen sulphite and $0.25 \mathrm{~mol} / 1$ sucrose, and filtered through four layers of cheese-cloth. A crude nuclear pellett was collected by centrifugation at $850 \mathrm{~g}$ for $20 \mathrm{~min}$ in the refrigerated Sorvall RC-2 centrifuge. The pellet was resuspended with a Dounce glass pestle homogenizer in the same buffer containing $5 \mathrm{~g} / 1$ Triton X-100 and centrifuged at $850 \hat{g}$ for $20 \mathrm{~min}$ through a medium consisting of $0.05 \mathrm{~mol} / 1 \mathrm{Tris} / \mathrm{HCl}, \mathrm{pH} 7.4,0.025 \mathrm{~mol} / 1 \mathrm{KCl}, 0.01 \mathrm{~mol} / 1$ $\mathrm{MgCl}_{2}, 0.024 \mathrm{~mol} / 1$ thiogly cerol, $5 \mathrm{mmol} / 1$ sodium hydrogen sulphite and $0.8 \mathrm{~mol} / 1$ sucrose. The pellet was resuspended in the same buffer and the nuclei were isolated by centrifugation in $2.2 \mathrm{~mol} / \mathrm{l}$ sucrose at $60,000 \mathrm{~g}$ for $90 \mathrm{~min}$.

Isolation and dissociation of chrom atin (see scheme, fig. 1)

After extraction of the informofers (RNP particles) by the method of Samarina et al. (17), chromatin was prepared essentially according to Graziano \& Huang (18). Chromatin proteins were separated from DNA by a method based essentially on that of Levy et al. (19).

The final gelatinous pellet, dispersed and swollen in water, was dissociated in $6 \mathrm{~mol} / 1 \mathrm{urea}, 0.4 \mathrm{~mol} / 1$ guanidine hydrochloride, $1.5 \mathrm{~mol} / 1$ sodium hydrogen sulphite, $2 \mathrm{mmol} / \mathrm{l}$ EDTA, $2 \mathrm{mmol} / \mathrm{l}$ dithiothreitol, $0.1 \mathrm{~mol} / 1 \mathrm{Na}_{3} \mathrm{PO}_{4}(\mathrm{pH} 7.0)$ to give a DNA concentration of about $1 \mathrm{~g} / \mathrm{l}$. The suspension was stirred continuously for $10 \mathrm{~h}$ at $4^{\circ} \mathrm{C}$. The partially dissociated chromatin was then sedimented by centrifugation at $180,000 \mathrm{~g}$ for $40 \mathrm{~h}$ at $4{ }^{\circ} \mathrm{C}$ in a $70 \mathrm{Ti}$ rotor (Beckman). The supernatant fraction containing some of the histones and non-histone chromosoma proteins was removed and stored for a brief period at $-20^{\circ} \mathrm{C}$. The pellet was resuspended in a small volume of $6 \mathrm{~mol} / 1$ urea, $3 \mathrm{~mol} / 1 \mathrm{NaCl}, 1.5 \mathrm{~mol} / 1$ sodium hydrogen sulphite, $2 \mathrm{mmol} / 1$ EDTA, $2 \mathrm{mmol} / \mathrm{l}$ dithiothreitol, $0.1 \mathrm{~mol} / 1 \mathrm{Na}_{3} \mathrm{PO}_{4}, \mathrm{pH} 7.0$, stirred continuously for $10 \mathrm{~h}$ at $4{ }^{\circ} \mathrm{C}$ and then sheared in an Ultra Turrax at $60 \mathrm{~V}$ for $3 \mathrm{~min}$. The DNA was then sedimented by centrifugation at $180,000 \mathrm{~g}$ for $40 \mathrm{~h}$. The supernatant,

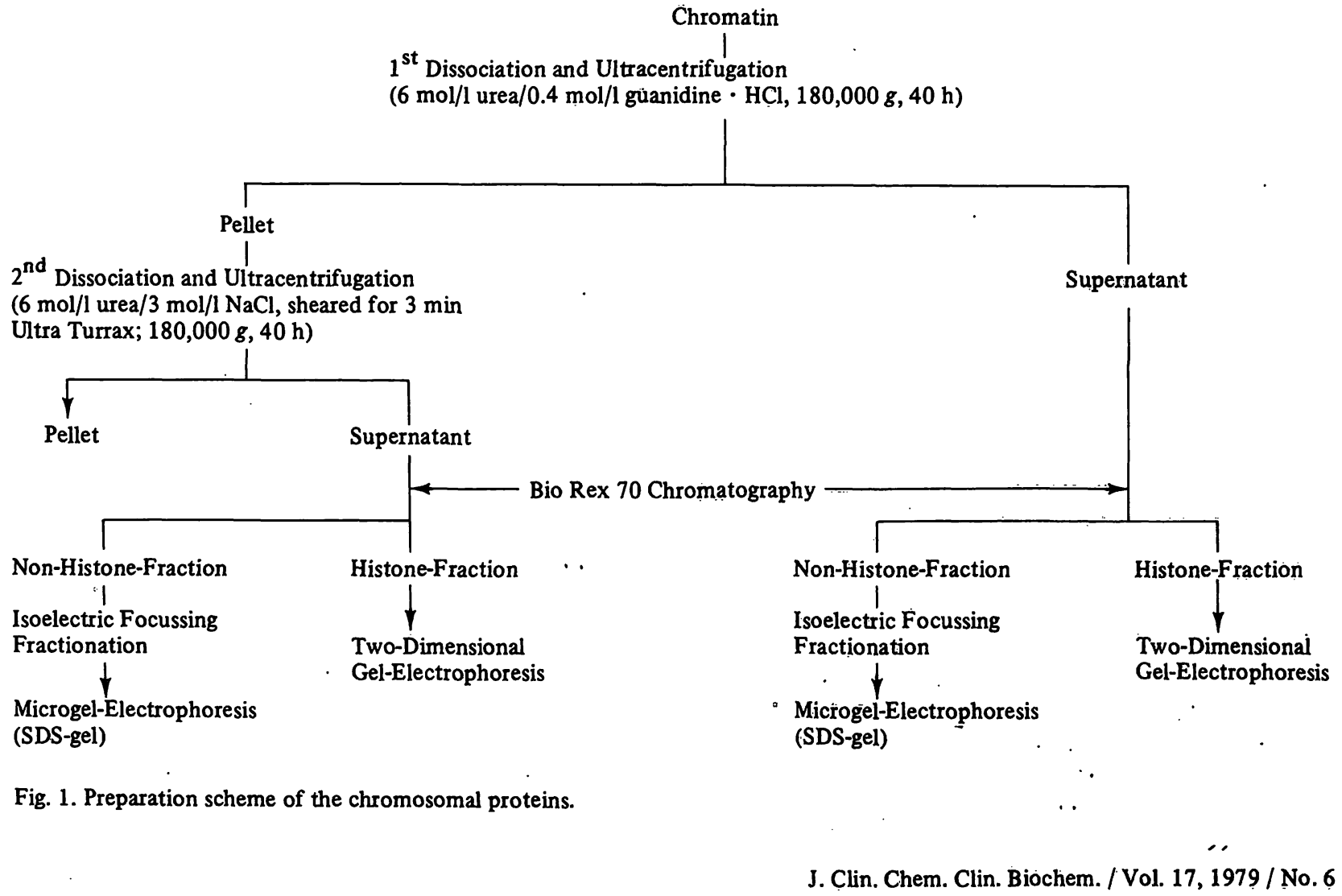


which contained $3 \mathrm{~mol} / 1 \mathrm{NaCl}$, was then dialyzed against $0.4 \mathrm{~mol} / 1$ guanidine hydrochloride solution. The samples obtained from both dissociation steps were then applied to BioRex 70 columns which had been equilibrated with $6 \mathrm{~mol} / 1$ urea, $0.4 \mathrm{~mol} / 1$ guanidine hydrochloride, $2 \mathrm{mmol} / 1$ dithiothreitol, $1.5 \mathrm{mmol} / 1$ sodium hydrogen sulphite, $2 \mathrm{mmol} / 1 \mathrm{EDTA}$, $0.1 \mathrm{~mol} / 1 \mathrm{Na}_{3} \mathrm{PO}_{4}$ (pH 7.0). The non-histone chromosomal proteins, which are acidic in nature and not adsorbed by BioRex 70 resins, were eluted with the equilibrating buffer. The histones that were adsorbed by the column were then eluted by raising the guanidine hydrochloride concentration of the buffer to $4 \mathrm{~mol} / \mathrm{l}$. The presence of proteins in the eluent was monitored by absorbance at $230 \mathrm{~nm}$. The non-histone chromosomal protein fractions were then dialyzed overnight against ammonium sulfate containing $2 \mathrm{mmol} / 1$ mercaptoethanol, $\mathrm{pH} 7$, to a final concentration of $4 \mathrm{~mol} / \mathrm{l}$. The precipitated protein was collected by centrifugation, redissolved in $7 \mathrm{~mol} / \mathrm{l}$ urea, $50 \mathrm{mmol} / 1$ dithiothreitol and incubated for $3 \mathrm{~h}$ at $37^{\circ} \mathrm{C}$.

The histone fractions were dialyzed overnight against $0.1 \mathrm{~mol} / 1$ acetic acid, $5 \mathrm{mmol} / 1$ mercaptoethanol, then precipitated by ethanol/ether/water (volumes, $30 \mathrm{ml}+10 \mathrm{ml}+10 \mathrm{ml}$ ) followed by centrifugation.

\section{Electrophoresis}

Fractionation of non-histone chromosomal proteins according to the method of zone convection electrofocussing

The non-histone chromosomal protein fractions, usually $0.1-0.15 \mathrm{~g} / 1$, were subjected to isoelectric focussing according to the method described by Valmet $(20)$ in a zone convection electrofocussing apparatus ( 29 chambers holding $50 \mathrm{ml}$ ), containing $6 \mathrm{~mol} / \mathrm{l}$ urea, $50 \mathrm{mmol} / 1$ dithiothreitol and $30 \mathrm{~g} / 1$ Ampholine (LKB, pH 3.5-10 range). The catholyte was $100 \mathrm{~g} / 1$ sucrose, $6 \mathrm{~mol} / \mathrm{l}$ urea and ethylene diamine, $\mathrm{pH} 1.5$, and the anolyte was $100 \mathrm{~g} / \mathrm{l}$ sucrose, $6 \mathrm{~mol} / \mathrm{l}$ urea and phosphoric acid, pH 10.5. Focussing lasted for approximately $60 \mathrm{~h}$ until the milli-amperage fell to a constant value. Protein concentration and $\mathrm{pH}$ were measured in each fraction.

Microgel electrophoresis according to Rüchel et al. (21, 22). Non-histone chromosomal proteins fractionated according to their isoelectric points in the Valmet apparatus were dialyzed against $5 \mathrm{mmol} / 1$ mercaptoethanol and lyophilized. The lyophilized protein fractions $(2 \mathrm{mg} / \mathrm{ml}$ protein) were dissolved in $0.035 \mathrm{~mol} / 1 \mathrm{Tris} / \mathrm{H}_{2} \mathrm{SO}_{4}$ buffer ( $\mathrm{pH} 8.6$ ) containing $10 \mathrm{~g} / 1$ SDS, $10 \mathrm{~g} / 1$ mercaptoethanol and $100 \mathrm{~g} / 1 \mathrm{glycerol}$, incubated at $100^{\circ} \mathrm{C}$ for $2 \mathrm{~min}$ and fractionated by polyacrylamide microgel electrophoresis according to the method of Rüchel et al. $(21,22)$. Pro tein samples of $2 \mu \mathrm{g}$ were layered onto the $10 \mu \mathrm{l}$ capillaries, with acrylamide concentrations increasing continuously from 10 to $400 \mathrm{~g} / \mathrm{l}$, and electrophoresed in a continuous buffer system $(0.05 \mathrm{~mol} / 1$ Tris/glycine, $\mathrm{pH} 8.4,1 \mathrm{~g} / 1 \mathrm{SDS})$ for about $2 \mathrm{~h}$ until the bromophenol-blue marker had reached the bottom of the gel. Gels were stained with $2 \mathrm{~g} / 1$ Coomassie Brilliant Blue in methanol/water (volumes, $500 \mathrm{ml}+500 \mathrm{ml}$ ), then made up to $70 \mathrm{~g} / 1$ with acetic acid before use. Destaining was done in $70 \mathrm{~g} / 1$ acetic acid by adding approximately $1 / 5 \mathrm{vol}$. methanol. The molecular weights of non-histone chromosomal proteins were estimated essentially as described by Weber \& Osborn (23), proteins with known molecular weights being used as standards. The gels were photographed and scanned at $570 \mathrm{~nm}$ by a densitometer attached to a Gilford spectrophotometter.

\section{Two-dimensional polyacrylamide gel electrophoresis of the} histone protein fractions

The histone protein fractions were separated by electrophoresis in pH 5.0 urea gels according to the method of Subramanian (24). The samples were prepared by lyophilization and dissolved in $6 \mathrm{~mol} / 1$ urea, $0.9 \mathrm{~mol} / 1$ acetic acid, $500 \mathrm{ml} / 1$ glycerol. After $2-3 \mathrm{~h}$ of preelectrophoresis at $2 \mathrm{~mA} / \mathrm{gel}$, the samples were loaded $(200 \mu \mathrm{g} / \mathrm{gel})$ and run for about $4 \mathrm{~h}$ at the same amperage. The second-dimensional slab gel was prepared by the method described by Subramanian (24), using a two-dimensional electrophoressis apparatus of dimensions $100 \times 100 \times 2 \mathrm{~mm}$. The anodic buffer was $0.028 \mathrm{~mol} / 1 \mathrm{Bis}-\mathrm{Tris} / \mathrm{HCl}, \mathrm{pH} 6.75$. The cathodic buffer contained $0.2 \%$ SDS, $0.07 \mathrm{~mol} / 1 \mathrm{Bis}-\mathrm{Triss}$
(Bis-(2 hydroxyethyl)imino)-tris (hydroxymethyl)methane), $0.07 \mathrm{~mol} / 1 \mathrm{MES}$ (2-(N-morpholino) ethanesulphonic acid), $\mathrm{pH} 6.5,0.3 \mathrm{~g} / 1$ thioglycerol. Electrophoresis was carried out at a constant current of $25 \mathrm{~mA}$ per slab for $6 \mathrm{~h}$. After removal from the cell, the slab was stained for $30 \mathrm{~min}$ at $55^{\circ} \mathrm{C}$ with $2 \mathrm{~g} / 1$ Coomassie Brilliant Blue in methanol/water (volumes $500 \mathrm{ml}+500 \mathrm{ml}$ ), then made up to $70 \mathrm{~g} / \mathrm{l}$ with acetic acid before use and destained with several changes of ethanol/water/ acetic acid (volumes, $25 \mathrm{ml}+65 \mathrm{ml}+8 \mathrm{ml}$ ). In some experiments, marker proteins of known molecular weight were incorporated into the second dimensional gel electrophoresis.

\section{Analy tical methods}

DNA was determined by the method of Burton (25), with calfthymus DNA as the standard. RNA was determined by the method of Ceriotti (26), with yeast RNA as the standard. Protein was determined according to the method of Lowry et al. $(27,28)$, with bovine serum albumin as the standard.

The amino acid analysis was carried out in Durrum autoanalyzer after hydrolyzing usually 50 to $100 \mu \mathrm{g}$ in $100 \mu \mathrm{l}$ of $6 \mathrm{~mol} / 1 \mathrm{HCl}$ $\left(110^{\circ} \mathrm{C}, 24 \mathrm{~h}\right)$.

\section{Results}

The ratio of absorption at 320 to $230 \mathrm{~nm}$ for each chromatin preparation was found to be less than 0.1 , which proves that the chromatin preparations were sufficiently pure. The native chromatin used throughout this study was characterized by a RNA/DNA ratio of 0.13 for proliferative, 0.11 for secretory endometrium or 0.14 for endometrial carcinoma and a protein/DNA ratio of $1.27,1.26$ or 1.23 (tab. 1). The chromatin, dissociated in $0.4 \mathrm{~mol} / \mathrm{l}$ guanidine hydrochloride, $6 \mathrm{~mol} / \mathrm{l}$ urea, phosphate buffer ( $\mathrm{pH}$ 7.0), was separated into DNA and chromosomal proteins by centrifugation at $180,000 \mathrm{~g}$ for $40 \mathrm{~h}$. Under these conditions at least $81 \%$ (proliferative endometrium), $79.3 \%$ (secretory endometrium), or $80.5 \%$ (carcinoma) of the chromosomal proteins was dissociated from DNA. $17.3 \%$, $18.9 \%$ and $16.9 \%$ of the total protein, respectively, appeared in the $180,000 \mathrm{~g}$ DNA sediment. After dissociation of the residual chromatin components $(180,000 \mathrm{~g}$ sediment) in $6 \mathrm{~mol} / \mathrm{l}$ urea, phosphate buffer ( $\mathrm{pH} \mathrm{7.0)}$ in the presence of $3 \mathrm{~mol} / \mathrm{l} \mathrm{NaCl}, 12.1 \%, 13.8 \%$ and $15.1 \%$ of the total protein, respectively, appeared in the $180,000 \mathrm{~g}$ supernatant. The sediment contained only a small amount of the total chromosomal proteins, which was tightly bound to DNA. It may be assumed that the combination of these two different dissociation steps was powerful enough to dissociate more than $95 \%$ of the total chromatin proteins from the DNA.

Most non-histone chromosomal proteins were then separated from the histones by stepwise elution on Bio Rex 70. The total amount of acidic non-histone chromosomal proteins was eluted free of histone with the equilibrating buffer. The nonabsorbed non-histone chromosomal proteins represented nearly $70 \%$ of total chromosomal proteins both for normal and neoplastic endometrium. Some strongly basic non-histone chromosomal proteins were retained with the histones on the ion-exchanger. The acidic non-histone chromosomal 
Tab. 1. Chemical composition of the human endometrial preparations from proliferative (6-10 day) and secretory (15-20 day) phase and from undifferentiated endometrial carcinoma (Neopl.).

\begin{tabular}{|c|c|c|c|c|c|c|c|c|c|c|c|c|}
\hline \multirow[t]{3}{*}{ Fraction } & \multirow{2}{*}{\multicolumn{2}{|c|}{$\begin{array}{l}\text { Total Protein } \\
(\%)\end{array}$}} & \multirow{3}{*}{ Neopl. } & \multicolumn{2}{|c|}{ Protein } & & \multicolumn{2}{|l|}{ RNA } & \multirow[b]{3}{*}{ Neopl. } & \multicolumn{3}{|c|}{ Histone } \\
\hline & & & & \multicolumn{2}{|r|}{ DNA } & \multirow[b]{2}{*}{ Neopl. } & \multicolumn{2}{|c|}{ DNA } & & \multirow[b]{2}{*}{ Prol. } & \multicolumn{2}{|c|}{ Nonhistone } \\
\hline & Prol. & Secr. & & Prol. & Secr. & & Prol. & Secr. & & & Secr. & Neopl. \\
\hline Native Chromatin & 100 & 100 & 100 & 1.27 & 1.26 & 1.23 & 0.13 & 0.11 & 0.14 & - & - & - \\
\hline $\begin{array}{l}0.4 \mathrm{~mol} / \mathrm{l} \\
\text { Guanidine-Dissociation }\end{array}$ & & & & & & & & & & - & & \\
\hline $\begin{array}{l}180,000 \mathrm{~g} \text { supernatant } \\
180,000 \mathrm{~g} \text { pellet }\end{array}$ & $\begin{array}{l}81.0 \\
17.3\end{array}$ & $\begin{array}{l}79.3 \\
18.9\end{array}$ & $\begin{array}{l}80.5 \\
16.9\end{array}$ & $\begin{array}{r}11.18 \\
0.25\end{array}$ & $\begin{array}{r}19.24 \\
0.26\end{array}$ & $\begin{array}{c}21.8 \\
0.21\end{array}$ & $\begin{array}{l}0.85 \\
0.05\end{array}$ & $\begin{array}{l}1.24 \\
0.04\end{array}$ & $\begin{array}{l}1.11 \\
0.03\end{array}$ & $\begin{array}{l}1.13 \\
-\end{array}$ & $\begin{array}{l}1.17 \\
-\end{array}$ & $\begin{array}{l}1.08 \\
-\end{array}$ \\
\hline \multicolumn{13}{|l|}{$3 \mathrm{~mol} / \mathrm{l} \mathrm{NaCl}$-Dissociation } \\
\hline $\begin{array}{l}180,000 \mathrm{~g} \text { supernatant } \\
180,000 \mathrm{~g} \text { pellet }\end{array}$ & $\begin{array}{r}12.1 \\
3.7\end{array}$ & $\begin{array}{r}13.8 \\
4.1\end{array}$ & $\begin{array}{r}15.1 \\
3.8\end{array}$ & $-\overline{0} 06$ & -0.06 & -0.05 & $\overline{0.04}$ & $\overline{0.04}$ & $\overline{0.04}$ & $\begin{array}{l}0.58 \\
-\end{array}$ & $\begin{array}{l}0.63 \\
-\end{array}$ & $\begin{array}{l}0.57 \\
-\end{array}$ \\
\hline
\end{tabular}

proteins were then separated in a zone convection electrofocussing apparatus according to Valmet (17), which combines high analytical resolution with high capacity. The results (fig. 2) from the preparative Valmet isoelectric focussing procedure indicate that the nonhistone chromatin mixture from the first dissociation step ( $0.4 \mathrm{~mol} / \mathrm{l}$ guanidine $\mathrm{HCl}, 6 \mathrm{~mol} / \mathrm{l}$ urea) has a quantitative maximum between $\mathrm{pH} 5.7$ to 6.7 for normal and neoplastic endometrium, while that of the second dissociation step ( $3 \mathrm{~mol} / 1 \mathrm{NaCl}, 6 \mathrm{~mol} / \mathrm{l}$ urea) is present in the $\mathrm{pH}$ range of 5.0 to 5.6 for proliferative,
5.7-6.7 for secretory endometrium and 5.0-5.6 for endometrial carcinoma, respectively. When concentrated protein fractions obtained after isoelectric focussing were subsequently analyzed by the highly sensitive microgelelectrophoresis technique, permitting the resolution of small amounts $(1-2 \mu \mathrm{g})$ of protein, it could be seen that the fractions in both dissociation steps were heterogeneous and contain discrete proteins unique to each fraction with very little overlap (fig. 3,4 ). The protein fractions consist of non-histone chromosomal proteins with molecular weights higher than 90,000 with
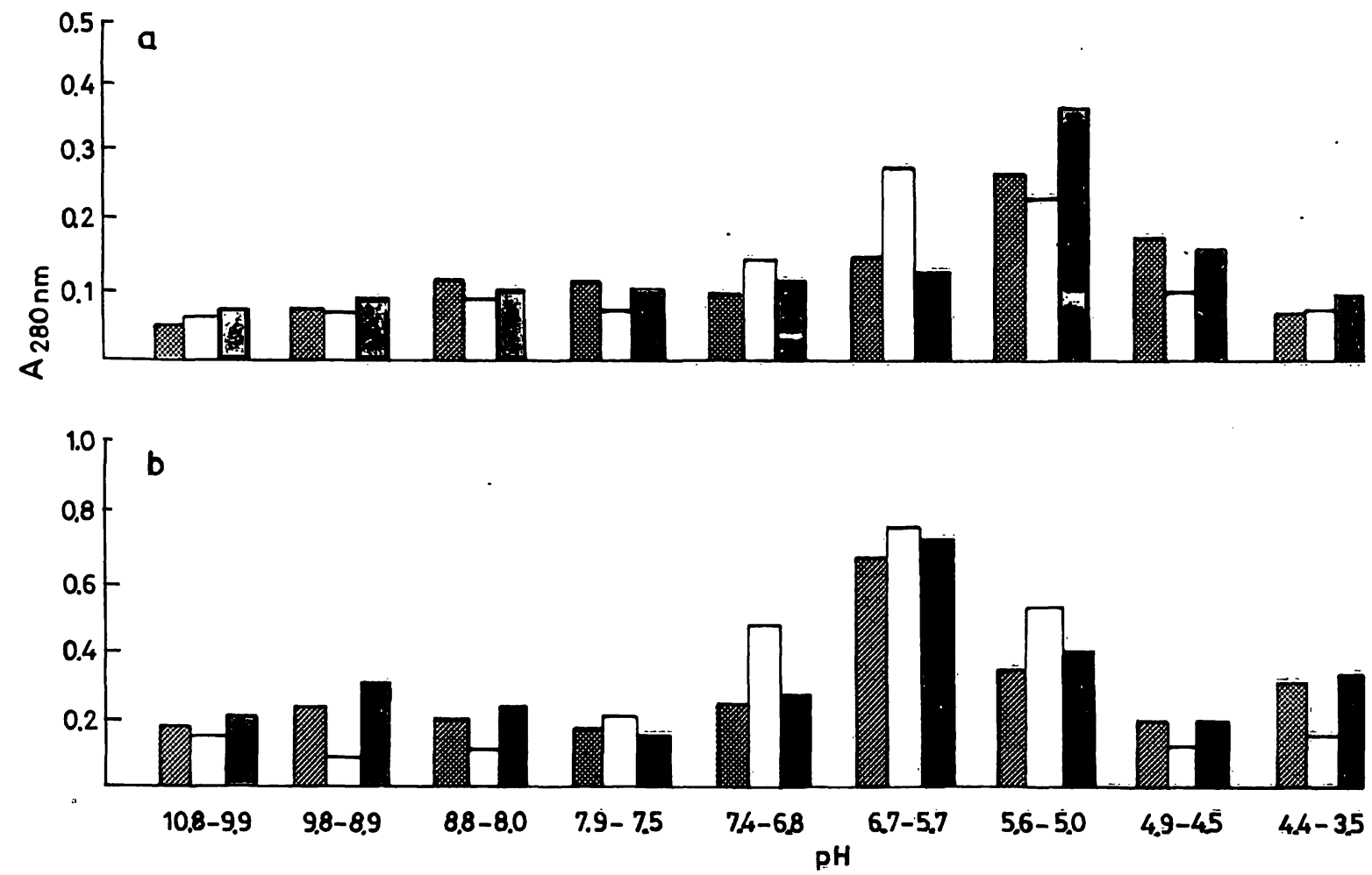

Fig. 2. pH-range of two-step dissociated non-histone chromosomal proteins (not adsorbed by Bio Rex 70) from human proliferative (hatched bars) and secretory endometrium (white bars) and undifferentiated endometrial (black bars) carcinoma.

Isoelectric focusing was peiformed in a zone convection electrofocusing apparatus; for detail see "Material and Methods".

a) Dissociation in $3 \mathrm{~mol} / 1 \mathrm{NaCl}$

b) Dissociation in $0.4 \mathrm{~mol} / \mathrm{l}$ guanidinium chloride 


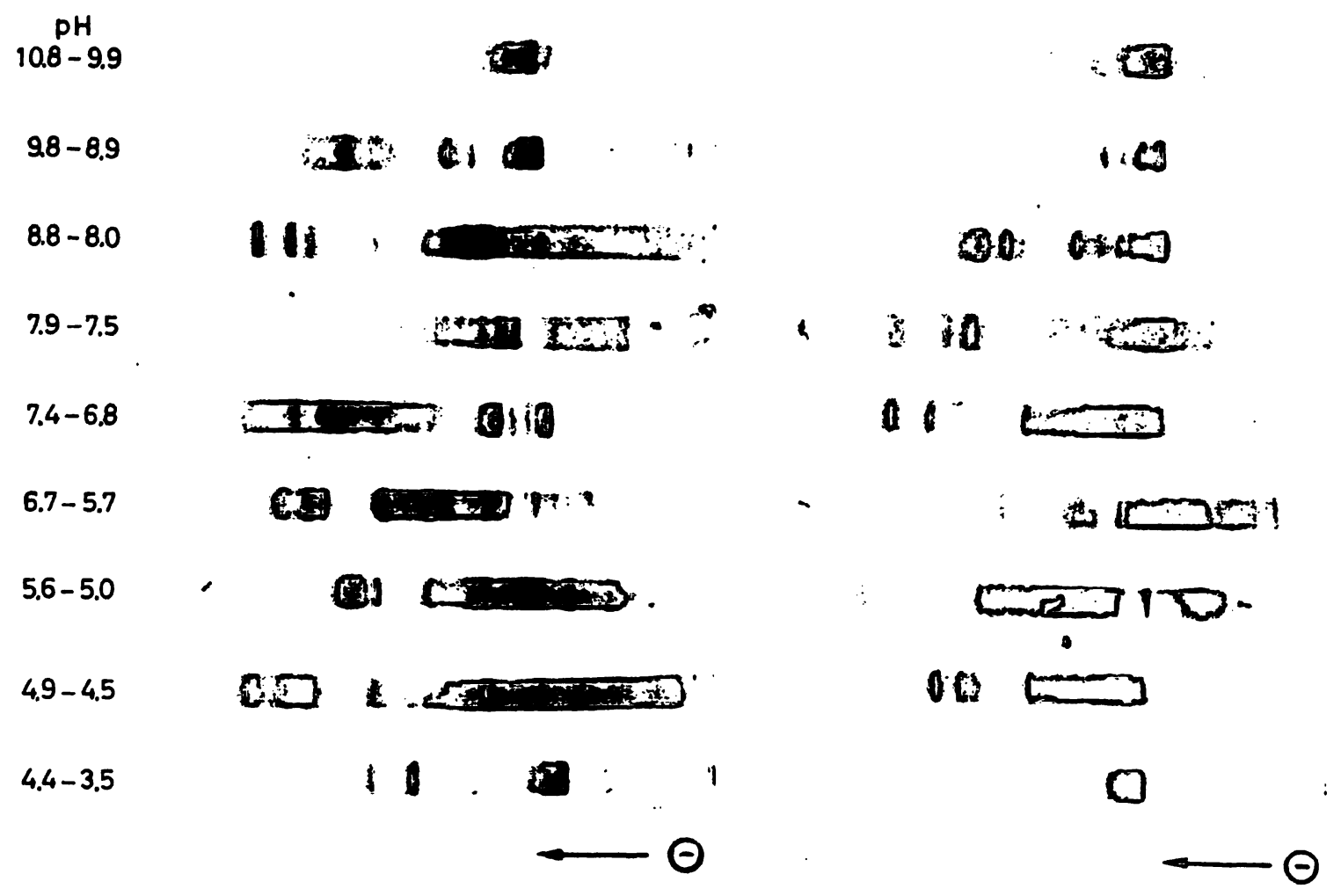

Fig. 3. Micro gel electrophoretic banding patterns of differentially dissociated non-histone chromosomal proteins from proliferative human endometrium separated by isoelectric focusing. - Equal amounts of protein $(2 \mu \mathrm{g})$ were used for micro gel electrophoresis. The gels were stained with Coomassie Brilliant Blue R 250, destained and photographed. pH-ranges were adapted to values of fig. 2.

a) Dissociation in $0.4 \mathrm{~mol} / \mathrm{l}$ guanidinium chloride

b) Dissociation in $3 \mathrm{~mol} / 1 \mathrm{NaCl}$

middle molecular weights mainly in the range between 40,000 to 90,000 , and low molecular weight $(40,000)$ polypeptides. It is important to note that the sum of all of the non-histone chromosomal protein components detected by means of photographic enlargements and optical scanning of the microgels is about 750 (fig. 3, 4). The gel patterns obtained were highly reproducible.

After the first dissociation step we observed 153 bands of released proteins in proliferative endometrium, 132 in secretory endometrium and 138 in endometrial carcinoma.

The quantitative distribution of non-histone chromosomal proteins in the various $\mathrm{pH}$ ranges shows more acidic than basic protein components.

$40 \%$ of the total non-histone chromosomal proteins are found in the supernatant after the second dissociation step: 117 protein components in proliferative, 107 in secretory endometrium and 108 in neoplastic tissue. Some similarities could be observed in non-histone chromosomal proteins patterns between normal proliferative and neoplastic endometrium, especially in the more basic non:histone chromosomal proteins fractions.

The proteins retained on Bịo Rex 70 were analyzed by two-dimensional gel electrophoresis. As shown in figure $5 \mathrm{a} / \mathrm{b} 53$ (proliferative endometrium), 36 (secretory endometrium) and 48 (undifferentiated endometrial carcinoma) components of apparently basic chromosomal proteins, which account for 10 to $20 \%$, together with all five histone fractions, can be visually identified. There are qualitative and quantitative differences between normal and neoplastic tissue.

The total heterogeneity of non-histone chromosomal proteins is further supported by the quantitative differences in the amino acid composition of the different fractions obtained after isoelectric focussing (tab. 2).

\section{Discussion}

The purpose of the present work was to analyze at high resolution the various non-histone chromosomal protein components under assorted hormone-induced functional conditions in normal and neoplastic endometrium. We used a combination of preparative and analytical fractionating techniques $(13-15)$ to characterize the nonhistone chromosomal proteins chemically and to obtain information about the number of non-histone chromosomal proteins components. The method described here has the advantage over standard high-sensitivity gel electrophoresis systems (29-31), which are based on the autoradiography of labelled proteins, that only 1-2 $\mu \mathrm{g}$ protein per microgradient electrophoresis is needed to 
A

Proliferative Endometrium

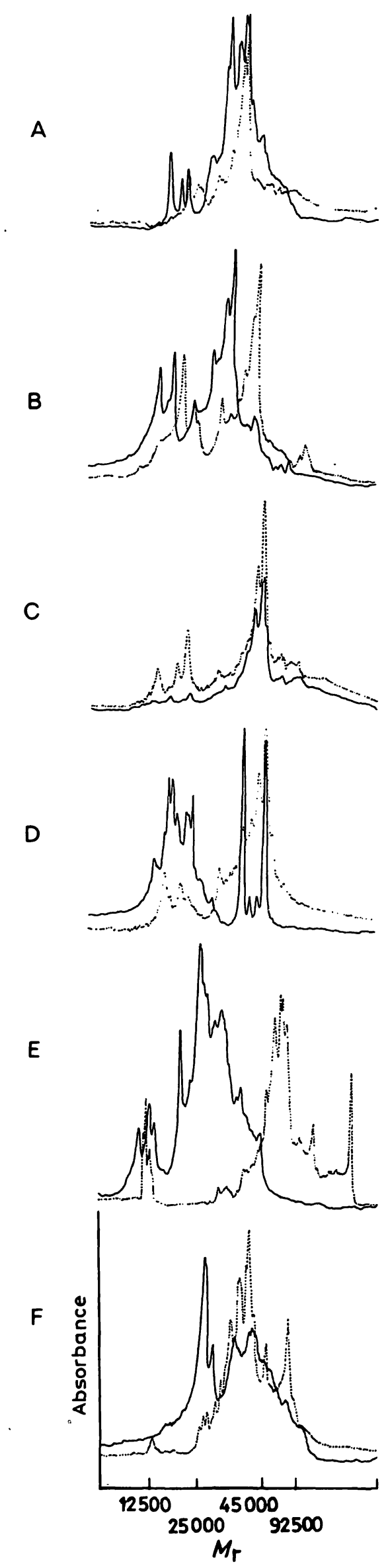

Secretory Endometrium
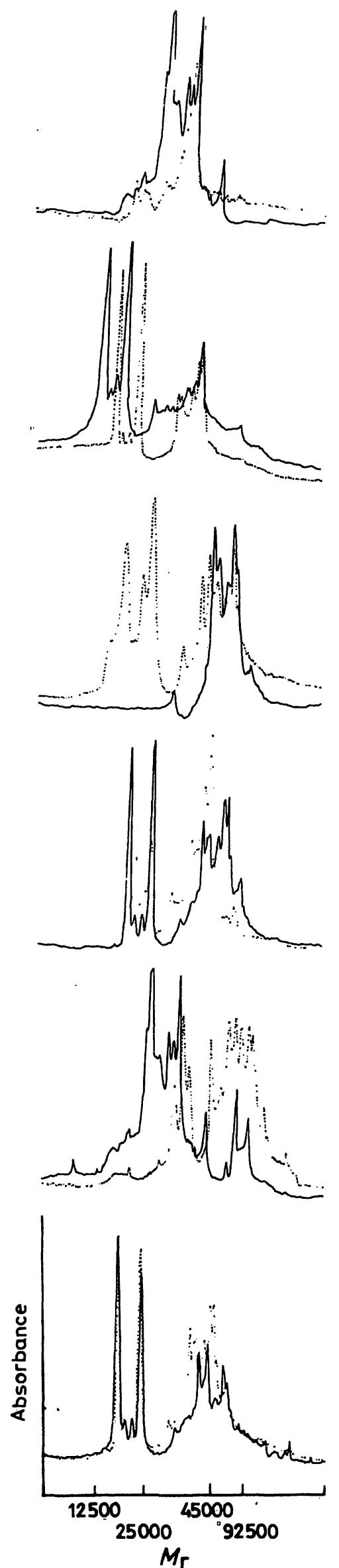

Carcinoma
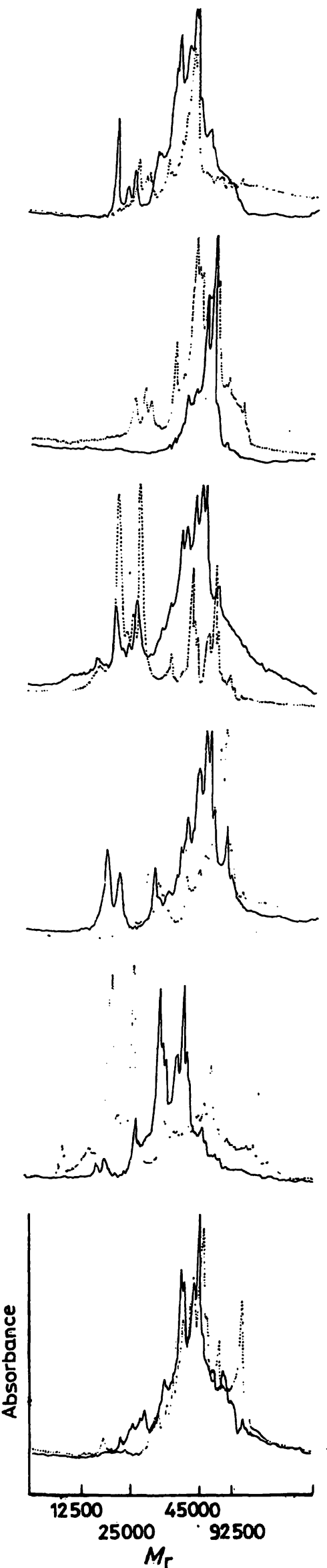

Fig. 4. 
Tab. 2. Amino acid analysis of nonhistone and histone proteins from proliferative human endometrium after dissociation with $0.4 \mathrm{~mol} / 1$ guanidine hydrochloride and $6 \mathrm{~mol} / 1$ urea. Non-histone chromosomal proteins were separated from histone proteins by Bio Rex 70 chromatography; non-histone chromosomal proteins were preparatively fractionated in a zone convection isoelectrofocussing apparatus.

Values are expressed in $\mathrm{mol} / 100 \mathrm{~mol}$ of recovered amino acids and are the average of two preparations. Corrections were made for hydrolytic losses.

\begin{tabular}{|c|c|c|c|c|c|c|c|c|c|c|}
\hline \multirow[t]{2}{*}{ Amino acid } & \multicolumn{10}{|c|}{ Protein fraction (pH-range) } \\
\hline & $3.5-4.4$ & $4.5-4.9$ & $5.0-5.6$ & $5.7-6.7$ & $6.8-7.4$ & $7.5-7.9$ & $8.0-8.8$ & $8.9-9.8$ & $9.9-10.8$ & Histones \\
\hline Aspartic acid & 11.3 & 12.8 & 10.8 & 9.8 & 9.2 & 9.1 & 8.8 & 8.3 & 8.1 & 5.3 \\
\hline Threonine & 5.8 & 4.7 & 5.3 & 5.2 & 5.7 & 4.3 & 5.1 & 5.3 & 5.4 & 5.7 \\
\hline Serine & 6.9 & 7.3 & 7.1 & 6.8 & 7.0 & 7.5 & 6.5 & 6.9 & 7.0 & 8.1 \\
\hline Glutamic acid & 12.8 & 11.9 & 10.1 & 9.3 & 9.7 & 8.8 & 8.3 & 8.5 & 7.8 & 7.4 \\
\hline Proline & 5.3 & 4.8 & 5.1 & 4.7 & 5.3 & 5.4 & 5.1 & 5.3 & 5.2 & 5.1 \\
\hline Glycine & 8.7 & 7.9 & 7.8 & 8.3 & 8.5 & 7.9 & 7.8 & 8.1 & 7.6 & 9.1 \\
\hline Alanine & 8.3 & 8.8 & 8.1 & 8.3 & 7.6 & 8.5 & 8.9 & 7.6 & 7.3 & 15.3 \\
\hline Valine & 6.7 & 6.3 & 6.1 & 7.0 & 6.9 & 6.3 & 7.1 & 6.8 & 6.5 & 6.8 \\
\hline Methionine & 0.8 & 1.1 & 0.6 & 0.3 & 0.9 & 1.3 & 0.8 & 0.7 & 0.6 & 0.3 \\
\hline Isoleucine & 4.8 & 4.2 & 4.5 & 4.1 & 3.9 & 4.8 & 4.0 & 4.7 & 4.2 & 3.1 \\
\hline Leucine & 8.5 & 7.8 & 7.9 & 8.1 & 8.0 & 8.3 & 7.8 & 8.1 & 7.6 & 7.0 \\
\hline Tyrosine & 2.5 & 2.7 & 2.1 & 3.1 & 2.5 & 2.6 & 2.8 & 2.0 & 2.4 & 2.3 \\
\hline Phenylalanine & 3.4 & 3.5 & 3.1 & 3.2 & 3.8 & 3.1 & 3.5 & 3.2 & 3.8 & 1.8 \\
\hline Histidine & 2.8 & 2.3 & 3.8 & 2.7 & 3.0 & 3.2 & 3.5 & 3.4 & 3.8 & 1.6 \\
\hline Lysine & 7.1 & 7.8 & 7.1 & 7.3 & 7.8 & 8.1 & 7.9 & 8.5 & 8.0 & 18.3 \\
\hline Arginine & 6.3 & 6.5 & 7.1 & 6.5 & 6.4 & 7.3 & 6.8 & 6.5 & 6.9 & 7.3 \\
\hline Acidic (A) & 24.1 & 24.7 & 20.9 & 19.1 & 18.9 & 17.9 & 17.1 & 16.8 & 15.9 & 13.1 \\
\hline Basic (B) & 16.2 & 16.6 & 18.0 & 16.5 & 17.2 & 18.6 & 18.2 & 18.4 & 18.7 & 27.2 \\
\hline$A / B$ & 1.49 & 1.49 & 1.16 & 1.16 & 1.1 & 0.97 & 0.94 & 0.91 & 0.85 & 0.48 \\
\hline
\end{tabular}

display the heterogeneity in a given IP region. With our methods, it was possible to identify, by Coomassie Blue staining, 270 non-histone chromosomal protein components in proliferative endometrium, 239 such components in secretory endometrium and 246 nonhistone chromosomal protein components in undifferentiated endometrial carcinoma. Without a functionbased test, it is difficult to determine the degree of contamination of the non-histone chromosomal proteins by cytoplasmic proteins. It may be that many proteins can function either in the cytoplasm or on the chromatin. It is known that cytoplasmic proteins diffuse into the cell nucleus and associate with the chromatin both in vivo and in vitro $(30,32)$. Sodium hydrogen sulphite was added as an inhibitor of proteolysis to prevent the formation of artefacts during the work up.

Qualitative and quantitative differences in the patterns of the protein bands from proliferative and secretory endometrium as well as endometrial carcinoma were observed. The specific alterations of these nuclear proteins during the menstrual cycle do not appear to be simply the result of an increase in the number of epithelial cells in the proliferative phase. Rather it seems likely that the differences reflect the difference in the hormonal influences on the endometrium during the menstrual cycle: Estradiol during the proliferative phase and the combination of progesterone and estradiol during the second half of the cycle.

We shall not know the extent to which the distinct differences in the chromosomal protein patterns of normal and neoplastic tissues are specifically related to the neoplastic transformation, until we know how many of the chromosomal proteins which we have isolated play a part in the regulation of the genetic apparatus.

The basic chromosomal pioteins adsorbed by Bio Rex 70 , which include the histone fraction, display no gel aggregation in the first dimension of two-dimensional separation on polyacrylamide gel. The "basic" nonhistone chromosomal proteins which were first described by Wang \& Johns (33) and later by Gronow \& Griffiths (34) and Elgin \& Bonner (35) are less heterogeneous than the socalled "acid" non-histone chromosomal proteins. However, there are distinct differences in the gel patterns of proliferative and secretory endometrium as well as endometrial carcinoma. It is possible that the differences in the electrophoretic mobility are due to various histone modifications (histones are modified post-

Fig. 4. Densitometric tracing of non-histone chromosomal proteins from proliferative and secretory human endometrium and undifferentiated endometrial carcinoma analyzed by microgel electrophoresis.

The lettering indicates the pH-range (adapted to values of fig. 3 ).

$\begin{array}{lll}\mathrm{A}=\mathrm{pH} 8.9-9.8 & \mathrm{~B}=8.0=8.8 & \mathrm{C}=7.5-7.9 \\ \mathrm{D}=\mathrm{pH} 6.8-7.4 & \mathrm{E}=5.7-6.7 & \mathrm{~F}=5.0-5.6\end{array}$

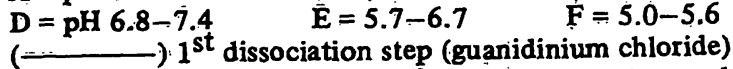

$(-----) 2^{\text {nd }}$ dissociation step $(\mathrm{NaCl})$

Molecular weights are estimated from the following marker proteins: cytochrome c $(12,500)$, chymotrypsinogen A $(25,000)$, aldolase $(45,000)$, phosphorylase a $(92,500)$. 

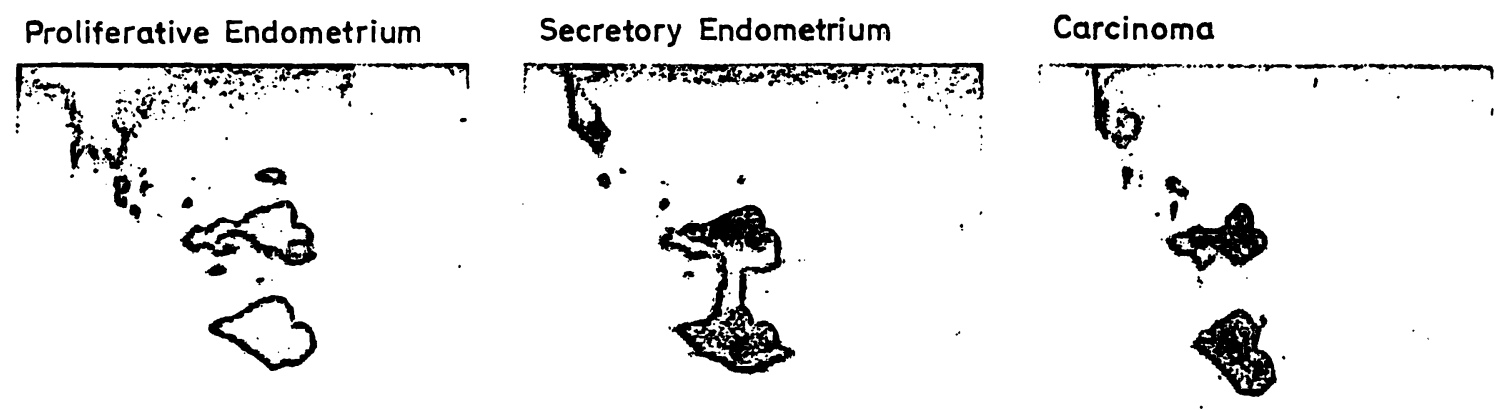

a
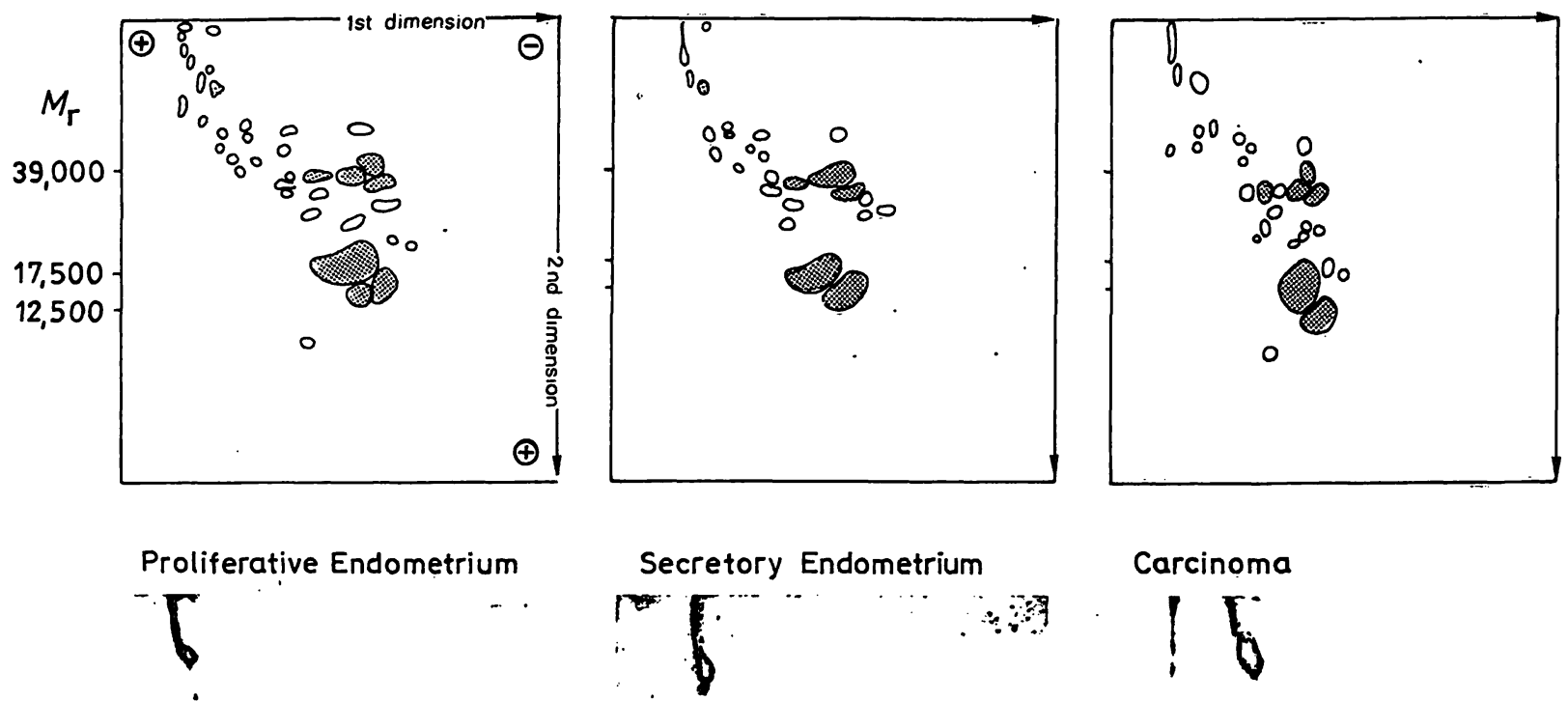

\section{Carcinoma

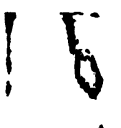

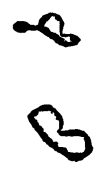
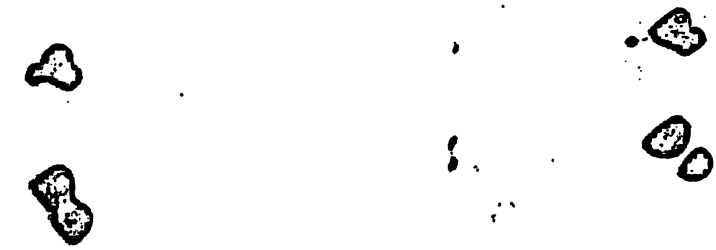

b
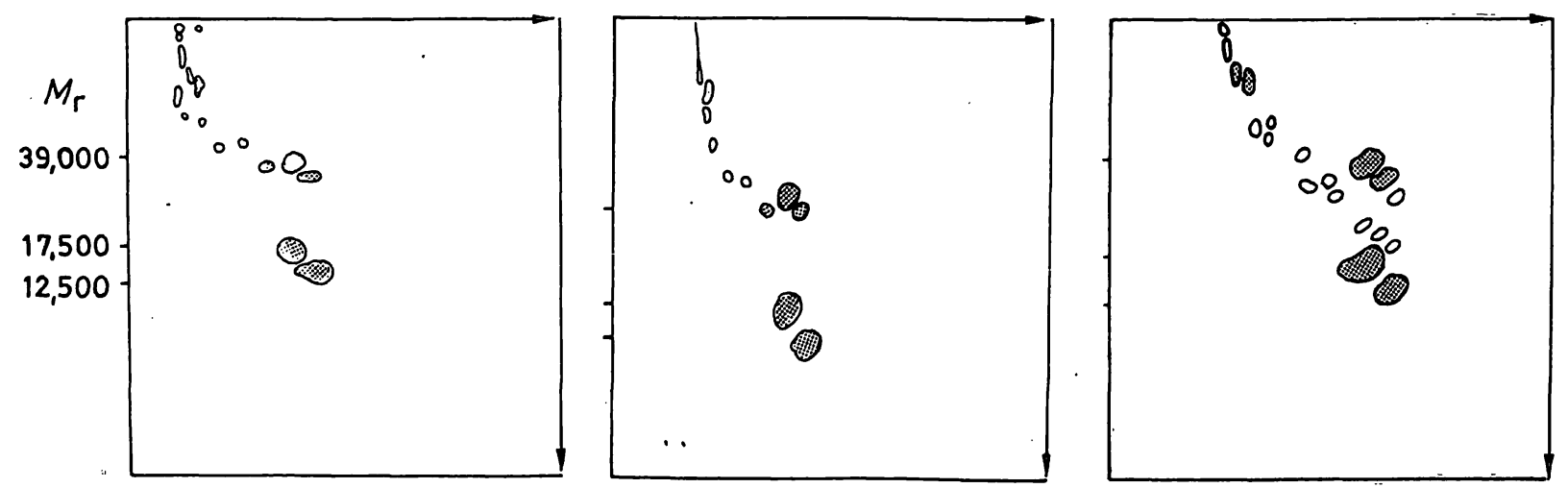

Fig. 5. Two-dimensional polyacrylamide gel electropherograms of the strongly basic chromosomal proteins (adsorbed by Bio Rex 70) from normal human proliferative and secretory endometrium and undifferentiated endometrial carcinoma.

Molecular weights are estimated from the following marker proteins: cytochrome c $(12,500)$, myoglobin typ II $(17,500)$ rabbit muscle aldolase $(39,500)$. The most dense and large spots are shaded, the less dense spots are open circles.

a) Dissociation in $0.4 \mathrm{~mol} / \mathrm{l}$ guanidinium chloride

b) Dissociation in $3 \mathrm{~mol} / 1 \mathrm{NaCl}$ 
synthetically by phosphorylation, methylation and acetylation). In addition, the histone $\mathrm{Hl}$ is believed to contain up to 6 subfractions, which differ from each other only by a few amino acids. Other histone subfractions, all with molecular weights between 14,000 and 19,000 , have been described $(36,37)$.

In this context, the recent results of Peterson \& McConkey (38), who compared the cytoplasmic and chromosomal proteins in induced and non-induced Friend Leukemia cclls, are rather surprising. Virtually all proteins in both cell fractions were the same in control and induced cells. About 4 to 6 differences were noted in chromatin and cytoplasm, out of a total of several hundred separated proteins. This result would imply a conservatism of the non-histone chromosomal proteins comparable to that of the histones, but it is contradicted by the qualitative and quantitative differences in the gel protein patterns of the chromosomal proteins from human endometrium described in this work and in other neoplastic systems (39-47). Finally, the question must be posed as to whether the methods for high resolution fractionation of chromosomal proteins described in this paper are capable of detecting the gene regulator proteins. In 1975, O'Farell (29) introduced a two-dimensional polyacrylamide gel electrophoresis technique capable of resolving at least

\section{References}

1. Holoubck, V. \& Crocker, T. Y. (1968), Biochim. Biophys. Acta 157, 352-361.

2. Stellwagon, R. \& Cole, R. (1969), Annu. Rev. Biochem. 38, 951-990.

3. Daly, M. M., Allfrey, V. G. \& Mirsky, A. E. (1952), J. Gen. Physiol. 36, 173-184.

4. Smellie, R., McIndoe, W. M. \& Davidson, J. N. (1953), Biochim. Biophys. Acta 11, 559-565.

5. Kamiyama, M. \& Wang, T. Y. (1971), Blochim. Biophys. Acta 228, 563-576.

6. Paul, J. \& Gilmour, R. S. (1968), J. Mol. Biol. 34, 305-314.

7. O'Malley, B. W., Spelsberg, T. C., Schrader, W. T., Chytil, F. \& Steggles, A. W. (1972), Naturc 235, 141-144.

8. Paul, J. (1972), Nature 238, 444-446.

9. McCure, M. E. \& Hnilica, L. S. (1970), Oncology (Clark, R. L., Cumley, R. W., McCay, J. E. \& Copeland, M. M., cds.) Year Book Medical Publishers, Inc., Chicago, Vol. I, pp. 494-509.

10. Stcin, G. S. \& Baserga, R. (1972), Adv. Cancer Res. 15, 287.

11. Weisenthal, L. M. \& Ruddon, R. W. (1972), Cancer Res. 32, 1009-1017.

12. Gerner, E. W. \& Humphrey, R. M. (1973), Biochim. Biophys. Acta 331, 117-127.

13. Krüger, C. \& Pollow, K. (1978), Anal. Biochem. 88, 388398.

14. Fleischer-Lambropoulos, H. \& Pollow, K. (1978), Biochem. Biophys. Res. Comm. 80, 773-780.

15. Heßlinger, H. \& Pollow, K. (1978), Molec. Biol. Rep. 4, 171-175.

16. Noyes, R. W., Hertig, A. T. \& Rock, J. (1950), Fertil. Steril. 1, 3-25.

17. Samarina, O. P., Lukanidin, E. M., Molmar, J. \& Georgiev, G. P. (1968), J. Mol. Biol. 33, 251-262.

18. Graziano, S. L. \& Huang, R. C. C. (1971), Biochemistry 10 , 4770-.4777.
1,000 proteins in a single pattern. Peterson \& McConkey (30) applied this new technique to the chromosomal proteins of HeLa cells. They found approximately 400 non-histone chromosomal proteins, and were able to detect as few as 500 copies of a single protein per haploid genome. Given the heterogeneity of about 250 chromosomal protein components found by the above authors, it would be seen that the limits of detection of the method described in this work are on the same order of magnitude.

Finally, it should be noted that the heterogeneity of the chromosomal protein patterns from endometrium at various stages of development supports the view that the non-histone chromosomal proteins play an important role in the control of transcription. After the description of the heterogeneity of the non-histone chromosomal proteins, the next step must be the identification of the physiological functions of this class of proteins, a step which, due to the complexity of the eucaryotic genome, will be extremely difficult to carry out.

\section{Acknowledgement}

We wish to thank Dr. B. Wittmann-Liebold (Max-Planck-Institut für Molckulare Genetik, Berlin) for the amino acid analysis.

19. Levy, S., Simpson, R. T. \& Sober, H. A. (1972), Bio chemistry 11, 1547-1554.

20. Valmet, E. (1969), Science Tools 16, 1.

21. Rüchel, R., Mesecke, S., Wolfram, D. I. \& Neuhoff, V. (1973), Hoppe-Seyler's Z. Physiol. Chem. 354, 1351-1368.

22. Rüchel, R., Richter-Landsberg, C. \& Neuhoff, V. (1975), Hoppe-Seyler's Z. Physiol. Chem. 356, 1283-1288.

23. Weber, K. \& Osborn, M. (1969), J. Biol. Chem. 244, 44064412.

24. Subramanian, A. R. (1974), Eur. J. Biochem. 45, 541-546.

25. Burton, K. (1956), Biochem. J. 62, 315-323.

26. Ceriotti, G. (1955), J. Biol. Chem. 214, 59-70.

27. Lowry, O., Rosebrough, N. J., Farr, A. L..\& Randall, R. J. (1951), J. Biol. Chem. 193, 265-275.

28. Oyama, V. I. \& Eagle, H. (1956), Proc. Soc. Exper. Biol. Med. 91, 305-312.

29. O'Farcll, P. H. (1975), J. Biol. Chem. 250, 4007-4021.

30. Peterson, J. L. \& McConkey, E. H. (1976), J. Biol. Chem. $251,548-554$.

31. Suria, D. \& Liew, C. C. (1974), Can. J. Biochem. 52 , 1143-1153.

32. Johnson, E. M., White, R. L., Finnegang, D. J. \& Hogness, D. S. (1975), J. Biol. Chem. 249, 4990-4999.

33. Wang, T. Y. \& Johns, E. W. (1968), Arch. Biochem. 124, 176-183.

34. Gronow, M. \& Griffiths, G. (1971), FEBS Lett. 15, 340344.

35. Elgin, S. C. R. \& Bonner, J. (1972), Biochemistry 11, $772-781$.

36. Wigle, D. T. \& Dixon, G. H. (1971), J. Biol. Chem. 246, 5636-5644.

37. Panyim, S. \& Chalkley, R. (1969), Biochem. Biophys. Res. Commun. 37, 1042-1049.

38. Pcterson, J. L. \& McConkey, E. H. (1976), J. Biol. Chem. $251,555-558$. 
39. Chin, J.-F., Brade, W. P., Thomson, J. A., Tsai, Y.-H. \& Hnilica, L. S. (1975), Exptl. Cell Res. 91, 200-206.

40. Orrick, L. R., Olson, M. O. Y. \& Busch, H. (1973), Proc. Natl. Acad. Sci. U. S. 70, 1316-1320.

41. Reeck, G. R. \& Morris, H. P. (1972), Proc. Am. Assoc. Cancer Res. 15, 29.

42. Stein, G. S., Criss, W. E. \& Morris, H. P. (1974), Life Sci. 14, 95-105.

43. Wilson, B., Lee, M. A., Vidali, G. \& Allfrey, V. G. (1975), Cancer Res. 35, 2954-2958.
44. Yeoman, L. C., Taylor, C. W., Jordan, J. J. \& Busch, H. (1973), Biochem. Biophys. Res. Commun. 53, 1067-1076.

45. Loeb, L. A., Ritz, E., Crenzet, C. \& Jami, J. (1976), Exptl. Cell Res. 103, 450-453.

46. Kadohama, N. \& Turkington, R. W. (1968), Cancer Res. 33, 1194-1201.

47. Gronow, M. \& Griffiths, G. (1974), Exptl. Pathol. 9, 73-78.

Professor Dr. Kunhard Polloww Institut für Molek'larbiologie und Biochemie Freie Universität Berlin

Arnimallee 22

D-1000 Berlin 33 


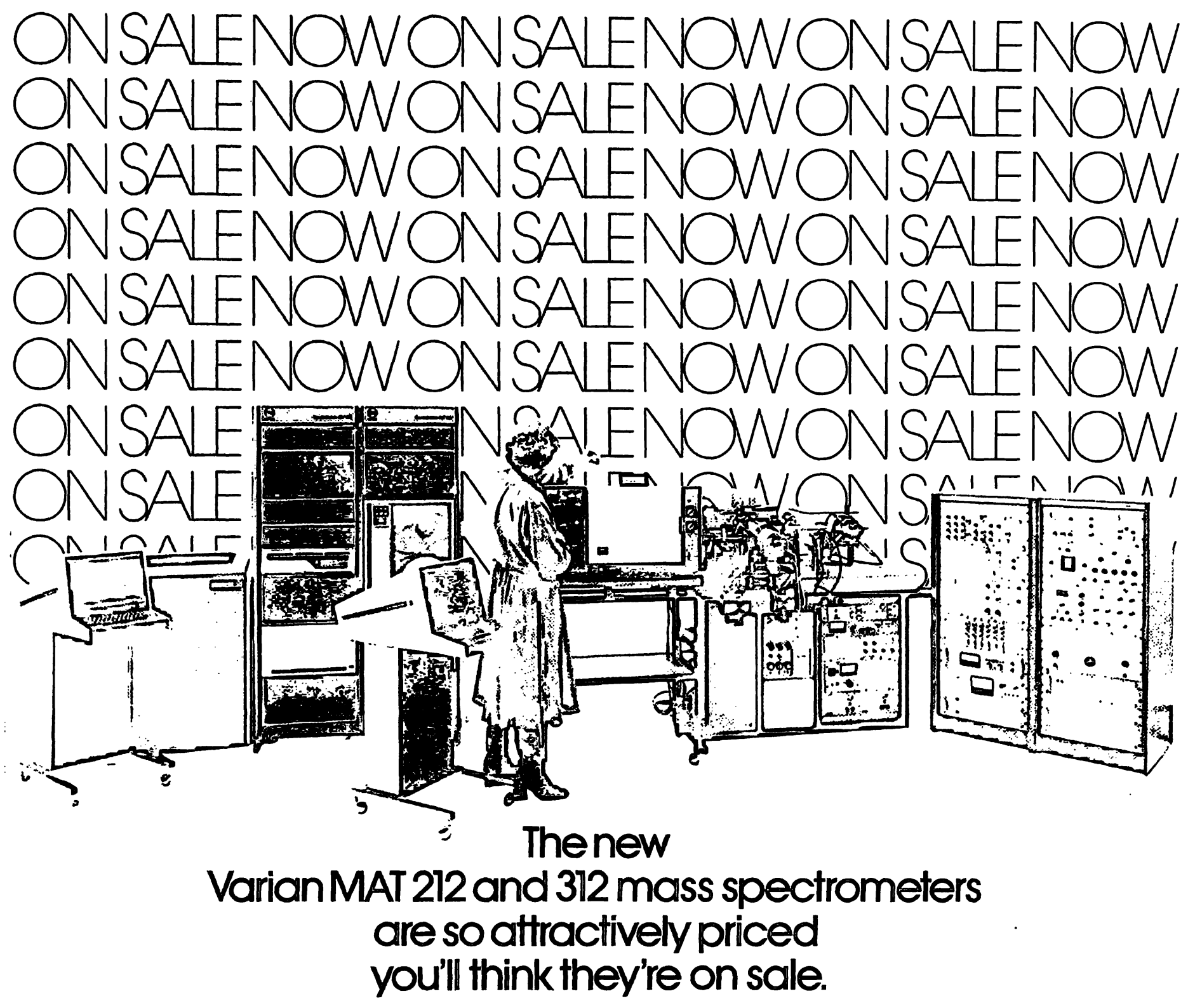

If you've always been a Varian admirer, now's an excellent opportunity to be a Varian owner.

Reason: Varian has put together some great "packages" combining our new

MAT 212 and 312 mass spectrometers with our popular SS 200 data systems which feature simultaneous data acquisition and evaluation.

And, whether a 212 or 312 package catches your eye, you'll like our irresistibly low prices.

The MAT 312 is an advanced version of our popular MAT $311 \mathrm{~A}$. It has an improved source with more accessories and greater versatility for applications including field desorption studies.

The versatile MAT 212 brings a proven track record to CI/El studies, not to mention such great options as GC/MS analysis with packed columns (jet separator); multi-ion selection analysis,

$\mathrm{DCl}$ (direct chemical ionization or desorption $\mathrm{Cl}$ ) collisional activation analysis, negative ion detection and much more.

Now; to the bottom line ... price. We suggest you call us. You'll be pleasantly surprised and may want to arrange a demonstration. For information or literature contact:

Performance ạt ạ glạç̣e!

\begin{tabular}{|c|c|}
\hline $\begin{array}{l}\text { MAT } 312 \\
\text { Resolving power: } \\
\text { Mass range: } \\
\text { Accuracy: }\end{array}$ & $\begin{array}{l}\text { up. to } 35,000 \text { ( } 10 \% \text { valley) } \\
1 \text { to } 3600 \text { amu } \\
\text { better than } 2 \text { ppm }\end{array}$ \\
\hline $\begin{array}{l}\text { MÁT } 212 \\
\text { Resolving power: } \\
\text { Mass range: } \\
\text { Accuracy: }\end{array}$ & $\begin{array}{l}\text { up to } 20,000 \text { ( } 10 \% \text { valley) } \\
1 \text { to } 1200, \text { switchable to } 3600 \text { amu } \\
\text { better than } 3 \text { ppm }\end{array}$ \\
\hline
\end{tabular}

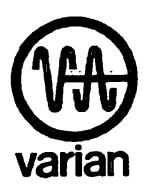

Varian MAT GmbH, Postfach 144062 Barkhausenstr. 2, 2800 Bremen 14 West-Germany, Phone (0421) 5493-1

Varian MAT Mass Spectrometry, 25 Hanover Road, Florham Park, NJ 07932, Phone (201) 822-3700 


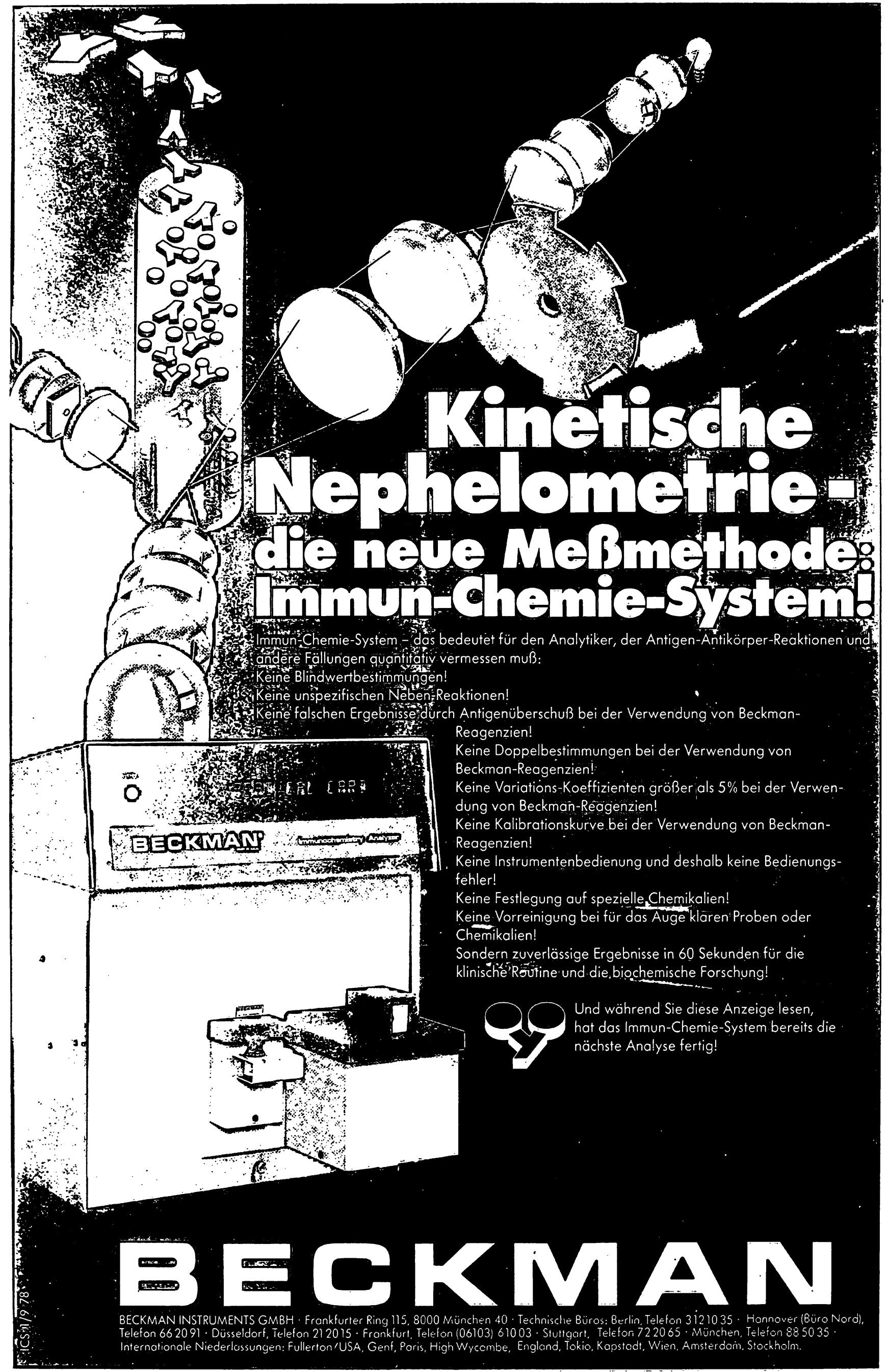

